\title{
STUDIES OF THE CARRIER STATE FOLLOWING INFECTION \\ WITH GROUP A STREPTOCOCCI. II. INFECTIVITY OF STREPTOCOCCI ISOLATED DURING ACUTE PHARYNGITIS AND DURING THE CARRIER STATE*
}

\author{
By RICHARD M. KRAUSE † AND CHARLES H. RAMMELKAMP, JR. \\ (From the Departments of Preventive Medicine and Medicine, Western Reserve University, \\ and the Streptococcal Disease Laboratory, Francis E. Warren Air Force \\ Base, Wyo.)
}

(Submitted for publication September 5, 1961 ; accepted October 6, 1961)

Group A streptococci persist in the tissues of the upper respiratory tract for several months after infection (1), although the number of streptococci that can be isolated from the respiratory tract usually decreases after the acute illness. The present study was designed to test the infectivity of group A streptococci isolated from the human oropharynx during the acute streptococcal infection and during the carrier state. Infectivity was determined by intranasal inoculation of monkeys, since in these animals streptococci will grow in the tissues of the oropharynx and induce an antibody response.

\section{METHODS}

The strains of group A streptococci employed were isolated from Patient 496 who developed exudative pharyngitis due to type 14 streptococci on March 21, 1951, in Cheyenne, Wyoming. He received no specific therapy and 2 weeks later was transferred by airplane to Florida (1). Cultures of the nose and oropharynx were obtained twice weekly by methods previously described (1). Colonies of bacteria showing $\beta$-hemolysis were isolated from the original sheep blood-agar plates and transferred to a second blood-agar plate. After incubation several colonies were inoculated into a blood-broth culture which was employed as the source of organisms for serological identification by the usual methods (2). A small quantity of the blood-broth culture was added to sterile milk and stored at $-20^{\circ} \mathrm{C}$.

For inoculation of animals, $0.75 \mathrm{ml}$ of the frozen culture was thawed at $37^{\circ} \mathrm{C}$ and transferred to $5 \mathrm{ml}$ of

* This investigation was conducted under the sponsorship of the Commission on Streptococcal and Staphylococcal Diseases and the Commission on Acute Respiratory Diseases, Armed Forces Epidemiological Board, and was supported by the Offices of the Surgeons General, Departments of the Army and the Air Force, Washington, D. C., and by the Helen Hay Whitney Foundation.

$\uparrow$ Present address: Rockefeller Institute for Medical Research, New York, N. Y. brain-heart infusion broth which contained one drop of sheep blood. After incubation at $37^{\circ} \mathrm{C}$ for 8 hours, $1 \mathrm{ml}$ was transferred into a flask containing $25 \mathrm{ml}$ of brainheart infusion and $0.5 \mathrm{ml}$ of sheep blood. The culture was incubated at $37^{\circ} \mathrm{C}$ for 12 hours, chilled, and centrifuged at $2,500 \mathrm{rpm}$ for 30 minutes. The sedimented organisms were resuspended in $10 \mathrm{ml}$ of sterile brainheart infusion broth. With a syringe and a blunt needle, $0.5 \mathrm{ml}$ of this suspension was inoculated into each nostril of unanesthetized monkeys; the procedure was repeated 24 hours later. It was demonstrated by pour-plate technique that the total inocula given to each monkey contained $\mathbf{4 0 0}$ to $\mathbf{7 8 0}$ million viable streptococci or clumps.

Cultures of the oropharynx, after the second inoculation, were obtained three times weekly for 5 weeks and then once a week for 4 weeks. Cultures were streaked on sheep blood-agar plates and the number of $\beta$-hemolytic colonies recorded. During the first week four colonies, and from subsequent cultures one colony, were selected for serological identification (2). Blood specimens for antistreptolysin $\mathrm{O}$ determinations (3) were drawn before and 3 weeks after inoculation.

Eleven young male and 9 young female rhesus monkeys were housed in individual cages. Frequent oropharyngeal cultures showed that 5 animals harbored group A streptococci and 4 carried group $\mathrm{C}$ or $\mathrm{G}$ organisms. All group $\mathrm{A}, \mathrm{C}$, and $\mathrm{G}$ streptococci were eliminated by penicillin therapy several weeks prior to inoculation.

\section{RESULTS}

Three strains of group A streptococci isolated from Patient 496 were employed in the monkey inoculation studies. The details of the illness of the patient are presented in Figure 1. Type 14 streptococci were isolated from the oropharynx for 11 weeks. Beginning in week 12 and extending through week 20 of observation, nontypable variants were consistently isolated. Strain 1 was isolated on the second day of illness from a blood-agar plate which showed a predominant growth of $\beta$-hemolytic colonies. Strain 2 


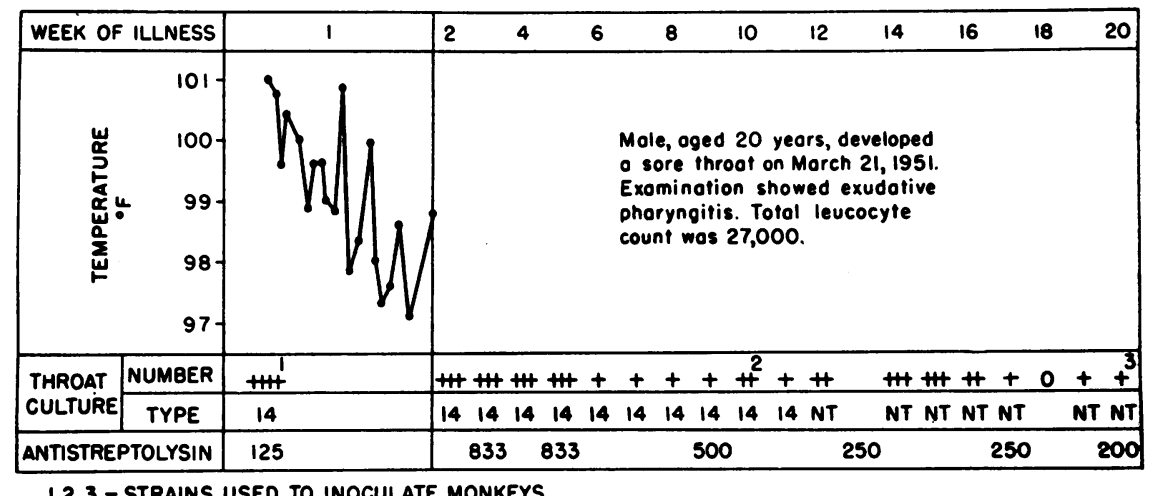

Fig. 1. Source of Strains for animal inoculations.

was isolated during week 10 of observation from a blood-agar plate which showed only a few $\beta$ hemolytic streptococci. Strain 3 was a nontypable variant isolated 20 weeks after the onset of illness and 8 weeks after the last isolation of a typable organism. The final strain, 3A, was obtained by repeated passage of strain 3 in the peritoneal cavities of mice. Extracts of this strain reacted strongly with type 14 antiserum.

The group and type of all strains were re- checked prior to inoculation. The acid extract of the nontypable strain 3 was concentrated with the alcohol precipitation technique (4), and no M substance was demonstrated serologically with the concentrated extract. The concentration of $M$ protein in the extracts of strains 1,2 , and $3 A$ was estimated by preparing twofold serial dilutions and noting the last dilution that gave a precipitin reaction with type 14 antiserum. Extracts of all three cultures showed the same titer of $\mathrm{M}$

TABLE I

Infectivity of strains of streptococci isolated at various times from a patient with type 14 pharyngitis

\begin{tabular}{|c|c|c|c|c|c|c|c|c|}
\hline \multicolumn{3}{|c|}{ Inoculum } & \multicolumn{6}{|c|}{ Results following intranasal inoculation } \\
\hline \multirow[b]{2}{*}{ Strain and date } & \multirow{2}{*}{$\begin{array}{l}\text { Week } \\
\text { isolated }\end{array}$} & \multirow{2}{*}{$\begin{array}{l}\text { Type of } \\
\text { strep. }\end{array}$} & \multirow[b]{2}{*}{ Monkey } & \multicolumn{3}{|c|}{$\begin{array}{c}\text { Number of } \beta \text {-hemolytic } \\
\text { strep. isolated* }\end{array}$} & \multicolumn{2}{|c|}{$\underset{\text { titer }}{\text { Antistreptolysin }}$} \\
\hline & & & & Day 1 & Day 3 & Day 6 & Before & After \\
\hline $\begin{array}{c}1 \\
3 / 22 / 51\end{array}$ & 1 & 14 & $\begin{array}{r}108 \\
97 \\
113 \\
91 \\
103\end{array}$ & $\begin{array}{r}0 \\
+ \\
+ \\
0 \\
++\end{array}$ & $\begin{array}{l}+++ \\
++ \\
++ \\
++ \\
+++\end{array}$ & $\begin{array}{r}+++ \\
++ \\
++ \\
++ \\
++\end{array}$ & $\begin{array}{r}50 \\
50 \\
50 \\
50 \\
125\end{array}$ & $\begin{array}{r}50 \\
50 \\
125 \\
250 \\
250\end{array}$ \\
\hline $\begin{array}{c}2 \\
5 / 28151\end{array}$ & 10 & 14 & $\begin{array}{r}112 \\
98 \\
99 \\
95 \\
101\end{array}$ & $\begin{array}{l}++ \\
++ \\
++ \\
++ \\
++\end{array}$ & $\begin{array}{l}+++ \\
+++ \\
+++ \\
+++ \\
+++\end{array}$ & $\begin{array}{l}+++ \\
+++ \\
+++ \\
+++ \\
+++\end{array}$ & $\begin{array}{r}50 \\
50 \\
50 \\
100 \\
50\end{array}$ & $\begin{array}{r}62 \\
83 \\
125 \\
250 \\
100\end{array}$ \\
\hline $\begin{array}{c}3 \\
7 / 31 / 51\end{array}$ & 20 & $\begin{array}{l}\text { Not } \\
\text { typ. }\end{array}$ & $\begin{array}{r}90 \\
105 \\
114 \\
104 \\
93\end{array}$ & $\begin{array}{c}0 \\
0 \\
++\dagger \\
+\neq \\
0\end{array}$ & $\begin{array}{r}0 \\
0 \\
+++ \\
+++ \\
0\end{array}$ & $\begin{array}{r}0 \\
0 \\
+++ \\
+++ \\
+++\end{array}$ & $\begin{array}{l}50 \\
50 \\
50 \\
50 \\
50\end{array}$ & $\begin{array}{r}50 \\
50 \\
125 \\
50 \\
159\end{array}$ \\
\hline $\begin{array}{c}\text { 3A } \\
\text { (Mouse passage } \\
\text { of strain 3) }\end{array}$ & 20 & 14 & $\begin{array}{r}110 \\
106 \\
96 \\
100 \\
102\end{array}$ & $\begin{array}{r}+ \\
+ \\
0 \\
++ \\
++\end{array}$ & $\begin{array}{r}+++ \\
+ \\
0 \\
++ \\
+++\end{array}$ & $\begin{array}{r}+++ \\
+ \\
+ \\
++ \\
++ \\
++\end{array}$ & $\begin{array}{r}50 \\
125 \\
62 \\
62 \\
125\end{array}$ & $\begin{array}{r}83 \\
159 \\
83 \\
500 \\
250\end{array}$ \\
\hline
\end{tabular}

* Number of $\beta$-hemolytic streptococci on blood-agar plate estimated as follows: $0=$ none, $+=1$ to $10,++=11$ to $50,+++=50$ or $>$. All colonies studied were group $A$ and identified as type 14 except: $\nmid$ three colonies identified, one type 14 and two not typable; $\ddagger$ four colonies identified as not typable. 
substance. The inoculum prepared with strain 3 , the non- $M$ variant, was streaked on a bloodagar plate, and from this plate 50 colonies were isolated and serologically identified. Extracts of all the colonies reacted with group A antiserum but not with the type 14 antiserum.

Inocula of each of the four strains, prepared as described, were administered intranasally to five monkeys. The results are presented in Table I. All of the 15 monkeys which received typable organisms-strains 1,2 , and 3A-became infected. Type 14 streptococci were readily isolated from the oropharynx of these 15 monkeys for at least 3 weeks and 13 monkeys showed an increase in the antistreptolysin $\mathrm{O}$ titer during the convalescent period. It is interesting that the five monkeys inoculated with strain 2 were more readily parasitized and consistently showed more $\beta$-hemolytic streptococci on culture of the oropharynx than did the monkeys inoculated with strains 1 or $3 \mathrm{~A}$.

Of the five monkeys inoculated with the strain 3 nontypable variant, three became infected. Identification of multiple colonies isolated on the first day after inoculation from Monkeys 114 and 104 showed two and four colonies, respectively, which were not typable and one colony from Monkey 114 which was type 14 . By the third day all colonies isolated from these animals reacted serologically with type 14 antiserum. The two animals which were not infected subsequently were shown to be susceptible to type 14 streptococci after intranasal inoculations.

\section{DISCUSSION}

Previous studies $(1,5)$ have shown that hemolytic streptococci may persist in the throat for many months after an acute infection. Hamburger, Green and Hamburger (6) designated the individual during the first few weeks of infection, when the nose culture was positive, as a "dangerous carrier." During this period many streptococci were dispersed into the environment in contrast to the slight contamination effected by the chronic pharyngeal carrier. Wannamaker (7) confirmed and extended these observations. His studies demonstrated that the dangerous carrier harbored large numbers of streptococci and was responsible for the spread of streptococcal infections. This spread was not mediated through the contaminated environment of the carrier, but rather by direct contact of the susceptible subjects with the dangerous carrier. The chronic carrier, on the other hand, harbored few organisms and was not responsible for the spread of infection. In the experiments reported here the infectivity for monkeys of streptococci isolated at different periods of the carrier state was examined.

The streptococci which persist in the throat many weeks or months after pharyngitis are frequently identical with the strain isolated at the time of infection (1). In the patient who served as the source of streptococci for these experiments the strains during the illness and the tenth week thereafter contained similar amounts of $\mathrm{M}$ protein. All monkeys inoculated with a strain from both of these periods of the carrier state developed persistently positive throat cultures for streptococci of the same type as the initial organism. No difference in infectivity for monkeys was detected between the two strains. It is conceivable that differences would have been detected if a smaller inoculum or other strains from different carriers had been used.

A frequently observed qualitative change of streptococci isolated during the course of the carrier state is the conversion to a variant that does not contain detectable amounts of $\mathrm{M}$ protein (1), and this phenomenon was observed in the patient who served as the source of streptococci for the monkey inoculations. A carrier after this change has occurred may be less dangerous than the recently infected subject, because the streptococci isolated at this later stage contain little or no $M$ protein. In this regard, Watson, Rothbard and Swift (8) observed that non-M protein variants did not infect monkeys after intranasal inoculation. The results of the present study support this observation. All 15 monkeys, which were inoculated in the nasopharynx with type $14 \mathrm{M}$ protein streptococci, developed the pharyngeal carrier state with this organism. None of the five monkeys inoculated with the non- $M$ variant of type 14 streptococci became infected with the variant form. From three of the five monkeys, however, type 14 organisms were subsequently isolated from the pharynx. This suggests that a reversion from the non- $M$ protein variant to an 
$M$ protein strain had occurred in the pharynx of the monkeys. Such a reversion of a non-M protein culture during repeated passages through mice is a common finding. Differences in the strains and experimental techniques may account for the fact that Watson and co-workers did not observe this reversion of the non-M protein strains in monkeys. An alternative explanation for the isolation of type 14 streptococci in monkeys inoculated with a non-M protein variant is the possibility of cross infections from monkeys inoculated with the type 14 streptococci. On the basis of experience with experimental pharyngeal infections in over 100 monkeys this possibility seems unlikely. In these extensive studies, in which monkeys were also housed in individual cages, no cross infections occurred.

The frequent occurrence of the nontypable variant during the course of the carrier state was documented in the previous paper (1). There is no information available, however, on the role of the non- $\mathrm{M}$ protein variant in the maintenance of streptococci in the human population. While epidemiological data on the spread of streptococcal infections have clearly demonstrated the infectivity of $\mathrm{M}$ protein organisms (7), it is not known whether non- $M$ protein variants may under special circumstances spread to susceptible hosts and cause infection by reversion to the typable form. The present study does emphasize that under appropriate laboratory conditions a non- $M$ protein variant will revert to an $M$ protein strain in the pharynx of monkeys. It is clear that additional investigations are needed to elucidate the mechanisms responsible for the infectivity of hemolytic streptococci.

\section{SUM MARY}

Strains of group A, type 14 streptococci isolated from a patient with acute pharyngitis during the acute illness and later during the carrier state caused infections in monkeys inoculated intranasally. Monkeys inoculated with a non-M variant of type 14, isolated during the twentieth week, were not infected with this organism. In three of the five monkeys inoculated with the non-M protein variant, the streptococci subsequently isolated from the pharynx were type 14 .

\section{REFERENCES}

1. Krause, R. M., Rammelkamp, C. H., Jr., Denny, F. W., Jr., and Wannamaker, L. W. Studies of the carrier state following infection with group A streptococci. I. Effect of climate. J. clin. Invest. 1962, 41, 568.

2. Swift, H. F., Wilson, R. T., and Lancefield, R. C. Typing group A hemolytic streptococci by $\mathrm{M}$ precipitin reactions in capillary pipettes. J. exp. Med. 1943, 78, 127.

3. Hodge, B. E., and Swift, H. F. Varying hemolytic and constant combining capacity of streptolysins: Influences on testing for antistreptolysins. J. exp. Med. 1933, 58, 277.

4. Lancefield, R. C. The antigenic complex of Streptococcus haemolyticus. I. Demonstration of a typespecific substance in extracts of Streptococcus haemolyticus. J. exp. Med. 1928, 47, 91.

5. Kuttner, A. G., and Krumwiede, E. Observations on the epidemiology of streptococcal pharyngitis and the relation of streptococcal carriers to the occurrence of outbreaks. J. clin. Invest. 1944, 23, 139.

6. Hamburger, M., Jr., Green, M. R., and Hamburger, V. G. The problem of the "dangerous carrier" of hemolytic streptococci. II. Spread of infection by individuals with strongly positive nose cultures who expelled large numbers of hemolytic streptococci. J. infect. Dis. 1945, 77, 96.

7. Wannamaker, L. W. The epidemiology of streptococcal infections in Streptococcal Infections, M. McCarty, Ed. New York, Columbia Univ. Press, 1954, p. 157.

8. Watson, R. F., Rothbard, S., and Swift, H. F. Typespecific protection and immunity following intranasal inoculation of monkeys with group A hemolytic streptococci. J. exp. Med. 1946, 84, 127. 